\title{
Burkitt lymphoma of the cavernous sinus presenting with acute onset third nerve palsy
}

\author{
Scott Sun $\odot$, ${ }^{1}$ Danielle M Levy, ${ }^{2}$ Michael Levy, ${ }^{3}$ John Ross Crawford ${ }^{4}$
}

${ }^{1}$ Department of Neurosciences, University of California San Diego, San Diego, California, USA

${ }^{2}$ Department of Neurosciences, University of California San Diego, La Jolla, California, USA ${ }^{3}$ Neurosurgery, University of California San Diego, San Diego, California, USA

${ }^{4}$ Neurosciences and Pediatrics, University of California San Diego, La Jolla, California, USA

Correspondence to Dr John Ross Crawford; jrcrawford@ucsd.edu

Accepted 2 December 2021

\section{DESCRIPTION}

An 18-year-old man presented with a 1-week history of right-eye blurred vision and headache. Neurological examination revealed right-sided ptosis, mydriasis, ophthalmoplegia and anisocoria. Emergent MRI was performed demonstrating a right cavernous sinus mass abutting the pituitary gland with extension into the sella turcica (figure 1). The cavernous segment of carotid artery showed encasement without narrowing or aneurysm and the optic nerve was displaced cephalad with equivocal enhancement of optic sheath. The pituitary gland was displaced transversely with microlobulations at the interface with suggestion of pituitary invasion. Radiographic differential diagnoses included small round blue cell tumours such as leukaemia, lymphoma, sarcoma and metastatic disease. The patient underwent subtotal resection of the cavernous sinus tumour using an orbito-zygomatic approach without complication. Pathology revealed a small round blue cell neoplasm consisting of hyperchromatic nuclei and small amounts of cytoplasm with an increased proliferation as measured by Ki67 immunohistochemistry (figure 2). Immunophenotyping revealed an abnormal cell population comprising 59\% of CD45-positive lymphocytes showing a monoclonal B-cell population that expressed CD10/CD19/CD20 with kappa restriction, consistent with mature CD10-positive monoclonal B-cell lymphoproliferative disorder and a diagnosis of Burkitt lymphoma. Following a negative staging workup, the patient was treated with a standard regimen containing etoposide, prednisone, vincristine, cyclophosphamide, doxorubicin and rituximab, and has been disease free more than 6 years without resolution of the third nerve palsy.

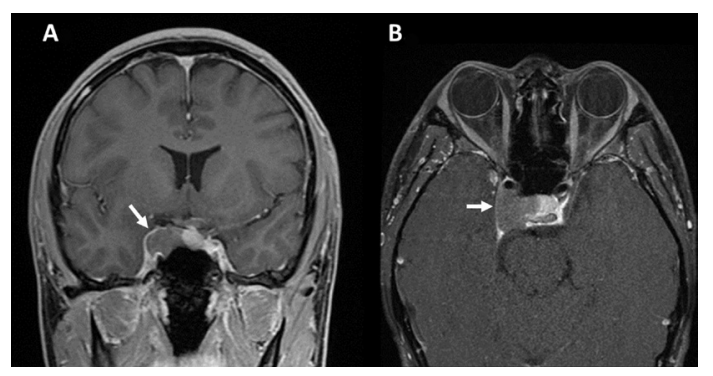

Figure 1 Neuroradiographic features of Burkitt lymphoma of the cavernous sinus. coronal (A) and axial (B) post gadolinium T1-weighted MRI sequences reveals a non-enhancing hypointense mass involving the right cavernous sinus with extension into the sella turcica and possible invasion into the pituitary (arrows).

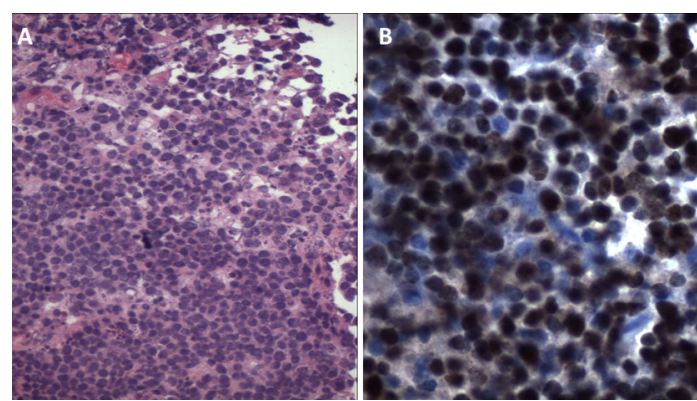

Figure 2 Pathological features of Burkitt lymphoma. pathology of the cavernous sinus mass revealed a small round blue cell neoplasm consisting of hyperchromatic nuclei and small amounts of cytoplasm (A) with an increased proliferation as measured by Ki67 immunohistochemistry (B). immunophenotyping revealed an abnormal cell population comprising $59 \%$ of CD45positive lymphocytes showing a monoclonal B-cell population that expressed CD10/CD19/CD20 with kappa restriction (not shown), consistent with mature CD10positive monoclonal B-cell lymphoproliferative disorder and a diagnosis of Burkitt lymphoma.

Among malignancies in adolescents and young adults, non-Hodgkin's lymphoma (NHL) has the fourth most common prevalence with higher incidence in the adolescent age group. ${ }^{1}$ Burkitt lymphoma, a subset of NHL arising from B lymphoblasts, accounts for half of all NHL paediatric cases and over $80 \%$ of childhood B-cell-NHL. ${ }^{12}$ While NHL manifestation is highly variable, presentation with acute neuro-ophthalmological abnormalities is especially uncommon with only a small number of cases in literature involving the cavernous sinus. ${ }^{3-5}$ Those prior reported cases involving the cavernous sinus presented with a cavernous sinus syndrome, with neurological symptoms including ophthalmoplegia and orbital pain. ${ }^{46}$ Neuroimaging features are not uniform and may be associated with intracranial extension and metastatic disease. ${ }^{2}{ }^{3}$ Early diagnosis and treatment of Burkitt lymphoma is critical as the condition may be curative in many cases following treatment with chemotherapy. ${ }^{1}$ In those patients presenting with symptomatic involvement of the cavernous sinus, it is unknown whether earlier treatment results in resolution of neurological abnormalities. Unfortunately, in the case of our patient, the third nerve palsy was persistent despite neuroradiological resolution of disease posttreatment. Our case highlights the neuroimaging features of Burkitt lymphoma presenting with acute onset third nerve palsy, thus expanding the differential diagnosis of cavernous sinus tumours. 


\section{Learning points}

Rapid onset of cranial neuropathies requires emergent neuroimaging to assess for vascular and structural lesions.

- Burkitt lymphoma may be a rare presentation of a cavernous sinus syndrome and should be included in the differential diagnosis of tumours involving the cavernous sinus.

- The neuroradiographic and clinical features of our case adds to the literature on presenting features of Burkitt lymphoma involving the central nervous system.

Contributors SS was responsible for the design and writing of the case report. DML was responsible for the design and writing of the case report. Dr DML was responsible for the design and writing of the case report. Dr JRC was responsible for the design and writing of the case report.

Funding The authors have not declared a specific grant for this research from any funding agency in the public, commercial or not-for-profit sectors.

Competing interests None declared.

Patient consent for publication Consent obtained directly from patient(s).

Provenance and peer review Not commissioned; externally peer reviewed.
Case reports provide a valuable learning resource for the scientific community and can indicate areas of interest for future research. They should not be used in isolation to guide treatment choices or public health policy.

\section{ORCID iD}

Scott Sun http://orcid.org/0000-0003-0787-2533

\section{REFERENCES}

1 Minard-Colin V, Brugières L, Reiter A, et al. Non-hodgkin lymphoma in children and adolescents: progress through effective collaboration, current knowledge, and challenges ahead. J Clin Oncol 2015;33:2963-74.

2 Johnson KA, Tung K, Mead G, et al. The imaging of Burkitt's and Burkitt-like lymphoma. Clin Radiol 1998:53:835-41.

3 Huisman TAGM, Tschirch F, Schneider JFL, et al. Burkitt's lymphoma with bilateral cavernous sinus and mediastinal involvement in a child. Pediatr Radiol 2003;33:719-21.

4 Kalina P, Black K, Woldenberg R. Burkitt's lymphoma of the skull base presenting as cavernous sinus syndrome in early childhood. Pediatr Radiol 1996;26:416-7.

5 Ceyhan M, Erdem G, Kanra G, et al. Lymphoma with bilateral cavernous sinus involvement in early childhood. Pediatr Neurol 1994;10:67-9.

6 Toro J, Burbano LE, Reyes S, et al. Cavernous sinus syndrome: need for early diagnosis. Case Rep Child Meml Hosp Chic 2015;2015. doi:10.1136/bcr-2014-206999. [Epub ahead of print: 27 Mar 2015].

Copyright 2021 BMJ Publishing Group. All rights reserved. For permission to reuse any of this content visit

https://www.bmj.com/company/products-services/rights-and-licensing/permissions/

BMJ Case Report Fellows may re-use this article for personal use and teaching without any further permission.

Become a Fellow of BMJ Case Reports today and you can:

- Submit as many cases as you like

- Enjoy fast sympathetic peer review and rapid publication of accepted articles

- Access all the published articles

- Re-use any of the published material for personal use and teaching without further permission

Customer Service

If you have any further queries about your subscription, please contact our customer services team on +44 (0) 2071111105 or via email at support@bmj.com.

Visit casereports.bmj.com for more articles like this and to become a Fellow 